\title{
By-Products of the Black Soybean Sauce Manufacturing Process as Potential Antioxidant and Anti-Inflammatory Materials for Use as Functional Foods
}

\author{
Shu-Ling Hsieh ${ }^{1}{ }^{\oplus}$, Yi-Wen Shih ${ }^{2}$, Ying-Ming Chiu ${ }^{3}$, Shao-Feng Tseng ${ }^{4}$, Chien-Chun $\mathrm{Li}^{5}$ and Chih-Chung $\mathrm{Wu}^{2, *}$ \\ 1 Department of Seafood Science, National Kaohsiung University of Science and Technology, \\ Kaohsiung 81157, Taiwan; slhsieh@nkust.edu.tw \\ 2 Department of Food and Nutrition, Providence University, Taichung 43301, Taiwan; a0922287120@gmail.com \\ 3 Department of Allergy, Immunology, and Rheumatology, Tungs' Taichung Metro Harbor Hospital, \\ Taichung 43503, Taiwan; ymcgreen@yahoo.com.tw \\ 4 Department of Quality Control and Research, Ta-Tung Soya Sauce Co. Ltd., Yunlin 64069, Taiwan; \\ blackbeanbeauty@gmail.com \\ 5 Department of Nutrition, Chung Shan Medical University, Taichung 40201, Taiwan; \\ chienchien367@gmail.com \\ * Correspondence: ccwumail@pu.edu.tw; Tel.: +886-4-26328001 (ext. 15318)
}

\section{check for} updates

Citation: Hsieh, S.-L.; Shih, Y.-W.; Chiu, Y.-M.; Tseng, S.-F.; Li, C.-C.; Wu, C.-C. By-Products of the Black Soybean Sauce Manufacturing Process as Potential Antioxidant and Anti-Inflammatory Materials for Use as Functional Foods. Plants 2021, 10, 2579. https://doi.org/10.3390/ plants10122579

Academic Editors: Juei-Tang Cheng, I-Min Liu and Szu-Chuan Shen

Received: 27 October 2021

Accepted: 23 November 2021

Published: 25 November 2021

Publisher's Note: MDPI stays neutral with regard to jurisdictional claims in published maps and institutional affiliations.

Copyright: (c) 2021 by the authors. Licensee MDPI, Basel, Switzerland. This article is an open access article distributed under the terms and conditions of the Creative Commons Attribution (CC BY) license (https:// creativecommons.org/licenses/by/ $4.0 /)$.

\begin{abstract}
To assess the potential of by-products of the black bean fermented soybean sauce manufacturing process as new functional food materials, we prepared black bean steamed liquid lyophilized product (BBSLP) and analysed its antioxidant effects in vitro. RAW264.7 macrophages were cultured and treated with BBSLP for $24 \mathrm{~h}$, and $1 \mu \mathrm{g} / \mathrm{mL}$ lipopolysaccharide (LPS) was then used for another $24 \mathrm{~h}$ to induce inflammation. The cellular antioxidant capacity and inflammatory response were then analysed. Activation of nuclear factor kappa B (NF- $\mathrm{kB}$ ) signaling in RAW264.7 macrophages was also analysed. Results showed BBSLP had 2,2-diphenyl-1-(2,4,6-trinitrophenyl)hydrazyl (DPPH) and 2,2'-azino-bis(3-ethylbenzothiazoline-6-sulfonic acid) diammonium $\left(\mathrm{ABTS}^{+}\right.$) radical-scavenging abilities and reducing power in vitro. The levels of both reactive oxygen species (ROS) and thiobarbituric acid reactive substances (TBARS) were reduced after RAW264.7 macrophages were treated with BBSLP after LPS induction. After RAW264.7 macrophage treatment with BBSLP and induction by LPS, the levels of inflammatory molecules, including nitric oxide (NO), prostaglandin $\mathrm{E}_{2}\left(\mathrm{PGE}_{2}\right)$, IL-1 $\alpha$, IL- 6 and TNF- $\alpha$, decreased. NF- $\kappa B$ signaling activity was inhibited by reductions in I $\mathrm{B}$ phosphorylation and NF- $\kappa$ B DNA-binding activity after RAW264.7 macrophages were treated with BBSLP after LPS induction. In conclusion, BBSLP has antioxidant and anti-inflammatory capabilities and can be a supplement material for functional food.
\end{abstract}

Keywords: black bean soybean sauce; by-product; antioxidant; inflammation; functional supplements

\section{Introduction}

Soybean sauces are commonly used as seasonings and sauces in Asia. Among them, black bean-fermented soybean sauce which uses black beans (Glycine max (L.) Merr.) as the major raw material is one of the most favored. During the soybean sauce manufacturing process, raw soybean steaming is an important step before yeast inoculation [1]. However, steamed soybean liquid waste, particularly by-products, may contain nutrients and other phytochemicals. These by-products may not only provide nutrient and active compounds for supplements but also possess sustainable and circular economic characteristics if they can be developed into a healthy food material. Considering global sustainability, the circular economy is a new alternative approach to the traditional economy [2]. Therefore, recycling certain by-products from food manufacturing processes as new food and pharmaceutical materials is not only a solution for food waste and supply issues, but also a new preferred resource for human health [2]. 
The black soybean cultivar has abundant polyphenols in its seed coating [3]. During the black soybean sauce manufacturing process, the beans are steamed at a high temperature and pressure [4]. This process is similar to soybean extraction with high-temperature steam under high pressure. These steamed soybean extracts contain polyphenols and some of the active components of black soybeans [5]. Previous studies have shown that black soybeans can reduce cardiovascular disease [6], regulate blood sugar [7] and have anticancer effects, [8,9], improve bone resorption in menopause [10], and possess antioxidative [11] and anti-inflammatory [12] properties. Kim et al. [13] showed that raw black soybeans have abundant total free polyphenols, flavonoids and phenolic acids. Anthocyanidin is a type of isoflavone that is present in black soybean coats [9]. Recycling this black soybean steamed liquid (BBSL) has the potential to providing an effective physiological material for functional food development.

The inflammatory response is a physiological protective mechanism of the body that occurs in response to infection; however, the occurrence of chronic inflammation with chronic inflammatory cells, including macrophages, lymphocytes and plasma cells, among others, is increasing [14]. During the inflammatory response process, reactive oxygen species (ROS), nitric oxide (NO) and prostaglandin $\mathrm{E}_{2}\left(\mathrm{PGE}_{2}\right)$ act as messengers for different physiological functions and pathological processes [15]. Conversely, intracellular cytokines, such as IL-1 $\beta$, IL-6, IL-10 and TNF- $\alpha$, are secreted from macrophages and lymphocytes [16]. These cytokines mediate the immune response and influence the macrophage microenvironment [17]. Excess or long-term chronic inflammation will lead to chronic diseases, such as cardiovascular disease (CVD), sepsis, diabetes mellitus (DM), and chronic kidney disease (CKD), increasing human health risks [18].

Some inflammatory response factors, such as IL-1 $\beta, \mathrm{IL}-6$, and TNF- $\alpha$, and inflammationmediated molecular enzymes, including inducible nitroxide synthase (iNOS) and cyclooxygenase-2 $(\mathrm{COX}-2)$, are primarily controlled by nuclear factor kappa $\mathrm{B}(\mathrm{NF}-\mathrm{kB})$, which is well recognized to play an important role in inflammation [15,19-22].

Currently, the food supply chain has many challenges due to decreased natural resources and increased food waste [23]. Thus, recycling reusable by-products of plant foods manufacturing process as new foods or components with active physiological effects is a forward-looking issue. For further more study and assessment the potential of this by-product of the soybean sauce manufacturing process on functional food material. The present study aims to investigate the capability of antioxidation and anti-inflammation of black bean steamed liquid lyophilized product (BBSLP).

\section{Results}

\section{1. $p H$ Value, Flavonoids, Total Phenol, and Protein Contents in BBSL and BBSLP}

To know the application of fresh BBSL, the $\mathrm{pH}$ was measured in this study. As shown in Table 1, the $\mathrm{pH}$ of fresh BBSL was $5.84 \pm 0.12$. The flavonoids, total phenol, and protein contents of BBSL were $11.5 \pm 1.5 \mathrm{mg}$ rutin equivalents (RUE) $/ \mathrm{mL}, 3.83 \pm 0.3 \mathrm{mg}$ gallic acid equivalents (GAE) $/ \mathrm{mL}$ and $3.5 \pm 0.8 \mathrm{mg} / \mathrm{mL}$, respectively (Table 1 ). In addition, after fresh BBSL was concentrated by a rotary vacuum dryer and frozen dry by a frozen dryer, the flavonoids, total phenol, and protein contents of BBSLP were $0.1 \pm 0.01 \mathrm{mg} R U E / \mathrm{mg}$, $0.03 \pm 0.01 \mathrm{mg} \mathrm{GAE} / \mathrm{mg}$ and $0.31 \pm 0.04 \mathrm{mg} / \mathrm{mg}$, respectively (Table 1 ).

Table 1. $\mathrm{pH}$, Flavonoids, total polyphenols and crude protein levels of BBSL and BBSLP.

\begin{tabular}{ccccc}
\hline & pH Value & Flavonoids & Total Polyphenols & Crude Protein \\
\hline BBSL $^{*}$ & $5.84 \pm 0.12$ & $11.5 \pm 1.5 \mathrm{mg} \mathrm{RUE} \mathrm{mL}^{-1}$ & $3.83 \pm 0.3 \mathrm{mg} \mathrm{GAE} \mathrm{mL}^{-1}$ & $3.5 \pm 0.8 \mathrm{mg} \mathrm{mL}^{-1}$ \\
BBSLP & - & $0.1 \pm 0.01 \mathrm{mg} \mathrm{RUE} \mathrm{mg}^{-1}$ & $0.03 \pm 0.01 \mathrm{mg} \mathrm{GAE} \mathrm{mg}^{-1}$ & $0.31 \pm 0.04 \mathrm{mg} \mathrm{mg}^{-1}$ \\
\hline
\end{tabular}

* BBSL: black bean steamed liquid; BBSLP: black bean steamed liquid lyophilized product; GAE: gallic acid equivalents; RUE: rutin equivalents. Values are presented as means $\pm \mathrm{SD}(n=3-5)$. 


\subsection{BBSLP Showed Antioxidant Effects In Vitro Conditions}

In the 2,2-diphenyl-1-(2,4,6-trinitrophenyl)hydrazyl (DPPH) radical-reducing ability test the scavenging abilities of $0.5,1$ and $2 \mathrm{mg} / \mathrm{mL}$ BBSLP were $42.5 \pm 8.7 \%, 54.4 \pm 0.4 \%$ and 79.6 $\pm 0.2 \%$, respectively. The observed scavenging ability in the vitamin C-treated group was $88.0 \pm 5.8 \%$ (Figure 1A). Although the DPPH radical-reducing ability in the BBSLP groups was lower than that in the vitamin $C$ group, it increased in a dose-dependent manner.

A

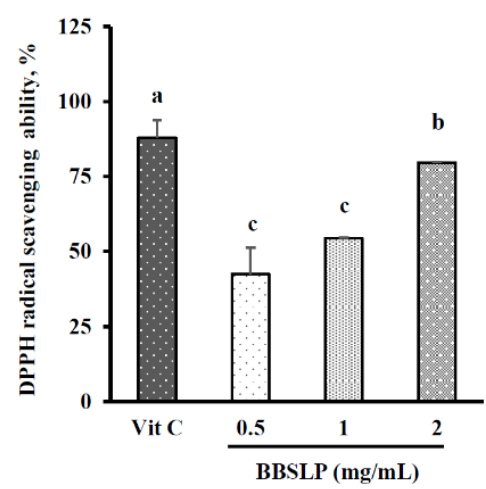

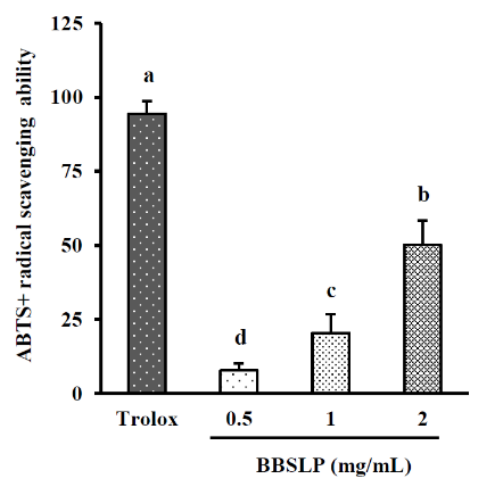

C

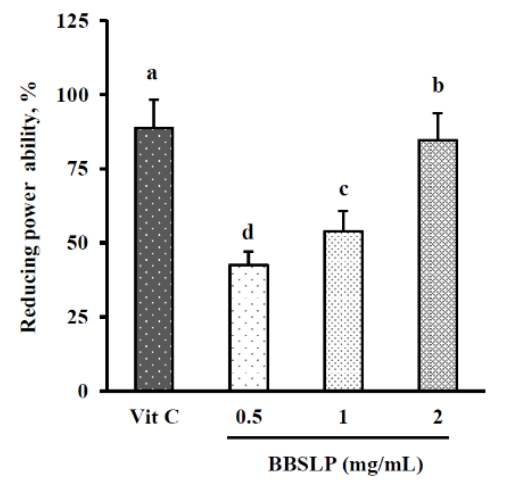

Figure 1. In vitro antioxidative ability of the BBSLP. DPPH radical scavenging activity (A), $\mathrm{ABTS}^{+}$radical scavenging activity (B) and reducing power $(\mathbf{C})$. Vitamin $\mathrm{C}$ was used as the positive control in the DPPH radical scavenging assay and reducing power ability assay, Trolox was used as the positive control in the $\mathrm{ABTS}^{+}$radical scavenging. Values are presented as means $\pm \mathrm{SD}(n=3-5)$. ${ }^{\text {abc }}$ Values are significantly different from the other groups as determined by Duncan's test $(p<0.05)$. Black bean steamed liquid lyophilized product (BBSLP).

The $\mathrm{EC}_{50}$ value of BBSLP for DPPH radical-scavenging ability was $0.81 \mathrm{mg} / \mathrm{mL}$. Figure 1B shows that the Trolox-treated group demonstrated $95.5 \pm 4.3 \% 2,2^{\prime}$-azinobis(3-ethylbenzothiazoline-6-sulfonic acid) diammonium $\left(\mathrm{ABTS}^{+}\right)$radical scavenging. The $\mathrm{ABTS}^{+}$radical scavenging abilities in the $0.5,1$ and $2 \mathrm{mg} / \mathrm{mL}$ BBSL groups were $7.8 \pm 2.3 \%$, $20.5 \pm 6.3 \%$ and $50.2 \pm 8.3 \%$, respectively, and showed a dose-dependent increase $(p<0.05)$. The effect concentration $\left(\mathrm{EC}_{50}\right.$ ) value of BBSLP for $\mathrm{ABTS}^{+}$radical scavenging ability was $1.50 \mathrm{mg} / \mathrm{mL}$. In addition, the reducing power of $0.5,1$ and $2 \mathrm{mg} / \mathrm{mL}$ BBSLP reached $42.5 \pm 84.6 \%$ in a dose-dependent manner $(p<0.05)$. The vitamin $C$-treated group showed $88.7 \pm 9.6 \%$ reducing power (Figure $1 \mathrm{C}$ ). The $\mathrm{EC}_{50}$ value of BBSLP for reducing power was $0.80 \mathrm{mg} / \mathrm{mL}$.

\subsection{BBSLP Maintained the Viability of RAW264.7 Macrophages after Lipopolysaccharide (LPS) Induction}

Our preliminary experimental results showed that the viability of RAW264.7 macrophages treated with 0.1 to $5 \mu \mathrm{g} / \mathrm{mL}$ BBSLP was not significantly different compared with that of the control cells (data not shown). For reasons related to BBSLP yield and solubility, we used $0.1,0.5$ and $1 \mu \mathrm{g} / \mathrm{mL}$ BBSLP as the experimental doses in the following study.

In the present study, the cell viability of RAW264.7 macrophages did not significantly differ between the $0.1,0.5$ or $1 \mu \mathrm{g} / \mathrm{mL}$ BBSLP (approximately $97-101 \%$ ) under LPS induction or the control group (100\%) (Figure 2A). Based on morphological examination results using inverted microscopy (Figure 2B), the cell number and morphology did not significantly differ between any BBSLP-treated group under LPS induction and the control group. Under LPS induction, RAW264.7 macrophage treatment with $0.1,0.5$, or $1 \mu \mathrm{g} / \mathrm{mL}$ BBSLP did not affect viability. 
A

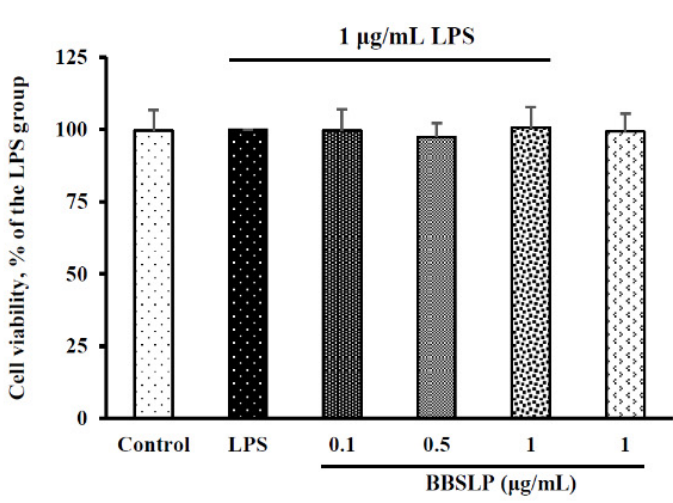

B

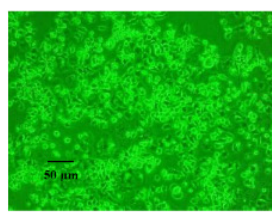

Control

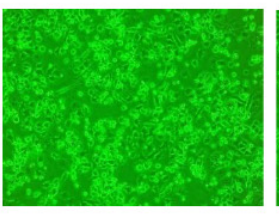

$0.5 \mu \mathrm{g} / \mathrm{mL}$ BBSLP + LPS

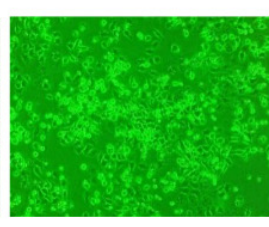

$1 \mu \mathrm{g} / \mathrm{mL}$ LPS

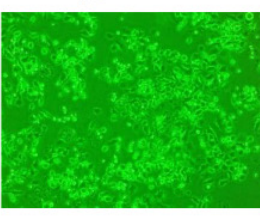

$1 \mu \mathrm{g} / \mathrm{mL}$ BBSLP + LPS

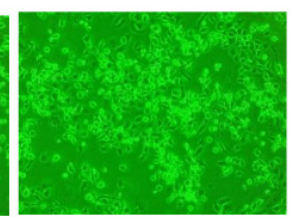

$0.1 \mu \mathrm{g} / \mathrm{mL}$ BBSLP + LPS

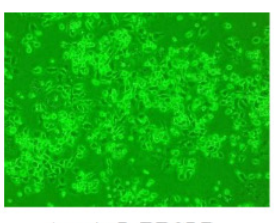

$1 \mu \mathrm{g} / \mathrm{mL}$ BBSLP

Figure 2. Effects of BBSLP on the viability of LPS-induced RAW264.7 cells. RAW264.7 cells $\left(1 \times 10^{5}\right.$ cells $/ 30$-mm plate) were seeded and cultured overnight, treated with $0.1,0.5$ or $1 \mu \mathrm{g} / \mathrm{mL}$ BBSLP for $24 \mathrm{~h}$ and then induced or not with $1 \mu \mathrm{g} / \mathrm{mL}$ LPS for another $24 \mathrm{~h}$. The group treated with $1 \mu \mathrm{g} / \mathrm{mL}$ LPS alone served as an induced control group. BBSLP was diluted in sterilized $\mathrm{H}_{2} \mathrm{O}$, and cells treated with sterilized $\mathrm{H}_{2} \mathrm{O}$ alone served as the control group. Cells treated with $1 \mu \mathrm{g} / \mathrm{mL}$ BBSLP without LPS treatment for $48 \mathrm{~h}$ were used as another control group. Cell viability (A) and morphological changes (B) were examined. Values are presented as means $\pm \mathrm{SD}(n=3-5)$.

\subsection{BBSLP Reduced Oxidative Stress in RAW264.7 Macrophages after LPS Induction}

When RAW264.7 macrophages were treated with LPS alone, the thiobarbituric acid reactive substances (TBARS) level was significantly increased by $229 \%(p<0.05)$ (Figure 3A). However, when RAW264.7 macrophages were treated with $0.1,0.5$ or $1 \mu \mathrm{g} / \mathrm{mL}$ BBSLP and then stimulated with LPS, the TBARS levels were significantly decreased by 38 to $70 \%$ compared with those in the LPS alone-treated group $(p<0.05)$ (Figure 3A). The TBARS levels in the group treated with only $5 \mu \mathrm{g} / \mathrm{mL}$ BBSLP did not differ from those in the control group. The ROS levels (100\%) of RAW264.7 macrophages treated with only LPS were significantly higher than those in control cells $(23.1 \pm 5.3 \%)(p<0.05)$ (Figure 3B). However, the ROS levels in RAW264.7 macrophages did significantly decrease in the groups treated with $0.1,0.5$ or $1 \mu \mathrm{g} / \mathrm{mL}$ BBSLP after stimulation with LPS (approximately $21.2-66.5 \%)(p<0.05)$.

A

B
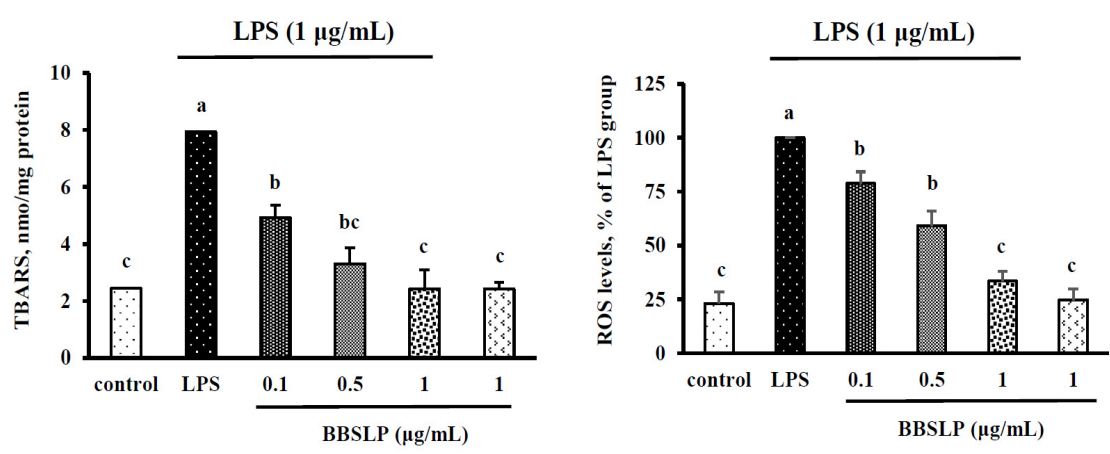

Figure 3. Effects of BBSLP on LPS-induced RAW264.7 cell oxidative stress. RAW264.7 cells $\left(1 \times 10^{5}\right.$ cells $/ 30$-mm plate $)$ were seeded and cultured overnight, treated with $0.1,0.5$ or $1 \mu \mathrm{g} / \mathrm{mL}$ BBSLP for $24 \mathrm{~h}$ and then induced or not with $1 \mu \mathrm{g} / \mathrm{mL}$ LPS for another $24 \mathrm{~h}$. The group treated with $1 \mu \mathrm{g} / \mathrm{mL}$ LPS alone served as an induced control group. BBSLP was diluted in sterilized $\mathrm{H}_{2} \mathrm{O}$, and cells treated with sterilized $\mathrm{H}_{2} \mathrm{O}$ alone served as the control group. Cells treated with $1 \mu \mathrm{g} / \mathrm{mL} \mathrm{BBSLP}$ without LPS treatment for $48 \mathrm{~h}$ were used as another control group. TBARS levels (A) and ROS levels (B) were examined. Values are presented as means \pm SD $(n=3-5)$. abc Values are significantly different from the other groups as determined by Tukey's test $(p<0.05)$. 


\subsection{BBSLP Reduced NO and PGE Production in RAW264.7 Macrophages after LPS Induction}

$\mathrm{NO}$ and $\mathrm{PGE}_{2}$ production was significantly increased after RAW264.7 macrophages were induced with LPS compared with the control group $(p<0.05$, Figure $4 \mathrm{~A}, \mathrm{~B})$. However, when RAW264.7 macrophages were cotreated with $1 \mu \mathrm{g} / \mathrm{mL}$ BBSLP and LPS, NO levels were decreased by $15 \%$ compared with those in the LPS group $(p<0.05)$. A $60-68 \%$ decrease in PGE $_{2}$ was noted in cells cotreated with 0.1 to $1 \mu \mathrm{g} / \mathrm{mL}$ BBSLP and LPS $(p<0.05)$. Immunoblot analysis showed that the iNOS levels in RAW264.7 macrophages treated with $0.1,0.5$ and $1 \mu \mathrm{g} / \mathrm{mL}$ BBSLP were $82 \%, 77 \%$ and $69 \%$ that of cells treated with LPS alone, respectively $(p<0.05$, Figure $4 \mathrm{C}, \mathrm{D})$ ). When RAW264.7 macrophages were treated with $0.1,0.5$ and $1 \mu \mathrm{g} / \mathrm{mL}$ BBSLP, the COX-2 protein levels were significantly reduced by $84 \%, 84 \%$ and $82 \%$, respectively, compared with those in the LPS-treated group $(p<0.05$, Figure $4 \mathrm{C}, \mathrm{D})$.

A

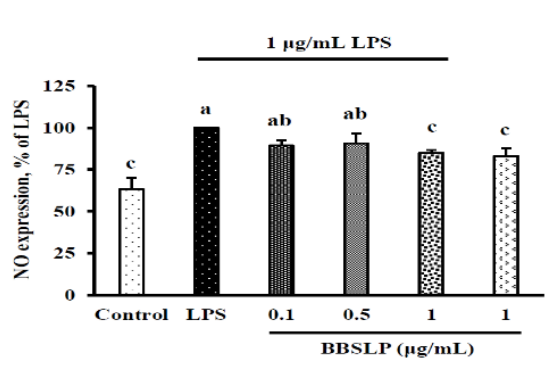

C

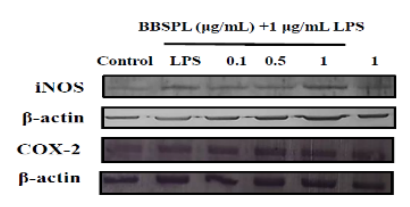

B
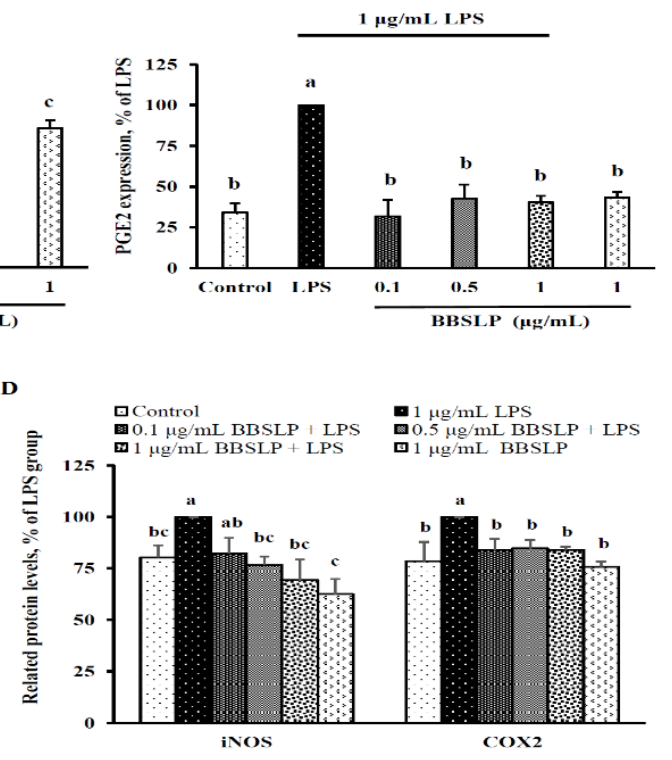

Figure 4. Effects of BBSLP on NO, PGE 2 , iNOS and COX-2 levels in RAW264.7 cells induced by LPS. RAW264.7 cells $\left(1 \times 10^{5}\right.$ cells $/ 30$-mm plate) were seeded and cultured overnight, treated with 0.1 , $0.5 \mathrm{or} 1 \mu \mathrm{g} / \mathrm{mL}$ BBSLP for $24 \mathrm{~h}$ and then induced or not with $1 \mu \mathrm{g} / \mathrm{mL}$ LPS for another $24 \mathrm{~h}$. The group treated with $1 \mu \mathrm{g} / \mathrm{mL}$ LPS alone served as an induced control group. BBSLP was diluted in sterilized $\mathrm{H}_{2} \mathrm{O}$, and cells treated with sterilized $\mathrm{H}_{2} \mathrm{O}$ alone served as the control group. Cells treated with $1 \mu \mathrm{g} / \mathrm{mL}$ BBSLP without LPS treatment for $48 \mathrm{~h}$ were used as another control group. NO (A), $\mathrm{PGE}_{2}(\mathbf{B}), \mathrm{iNOS}$ and COX-2 (C) protein expression and quantified iNOS and COX-2 levels (D) were examined. Values are presented as means $\pm \mathrm{SD}(n=3-5)$. ${ }^{\text {abc }}$ Values are significantly different from the other groups as determined by Tukey's test $(p<0.05)$.

\subsection{BBSLP Decreased IL-1 $\beta$, IL-6 and TNF- $\alpha$ Levels in RAW264.7 Macrophages after LPS Induction}

Figure 5A shows that the IL-1 $\beta$ level was significantly increased after an inflammatory response was induced in RAW264.7 macrophages by LPS compared with the control group $(p<0.05)$; however, when RAW264.7 macrophages were treated with 0.5 or $1 \mu \mathrm{g} / \mathrm{mL}$ BBSLP combined with LPS, the IL- $1 \beta$ levels were $59.9 \pm 8.7 \%$ and $32.0 \pm 8.7 \%$, they were significantly lower than the LPS induction alone group $(100 \%, p<0.05$, Figure $5 \mathrm{~A})$. The IL-6 levels in RAW264.7 cells decreased significantly by $7 \%$ after treatment with $1 \mu \mathrm{g} / \mathrm{mL}$ BBSLP compared with those after LPS induction alone $(p<0.05$, Figure 5B). Figure 5C also shows that the TNF- $\alpha$ level in the group treated with only $1 \mu \mathrm{g} / \mathrm{mL}$ BBSLP decreased significantly compared with the LPS alone group ( $p<0.05$, Figure 5B). Notably, IL-10 production did not differ among the control group, LPS-treated group, the group treated 
with various concentrations of BBSLP combined with LPS, and the group treated with BBSLP alone (Figure 5D).

A

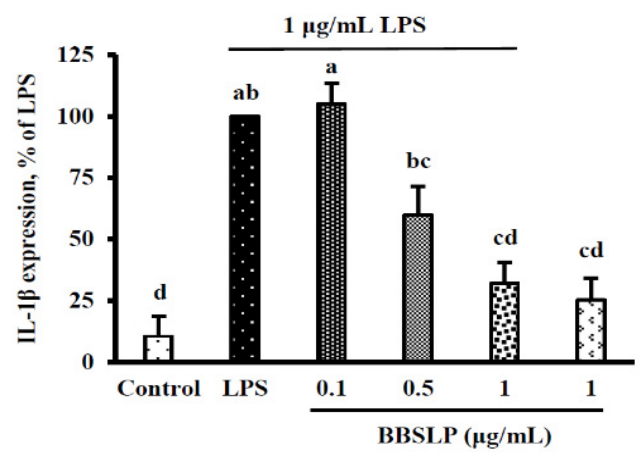

C

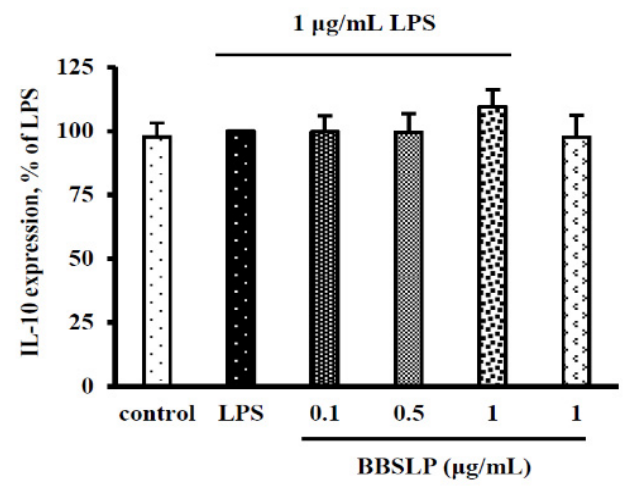

B

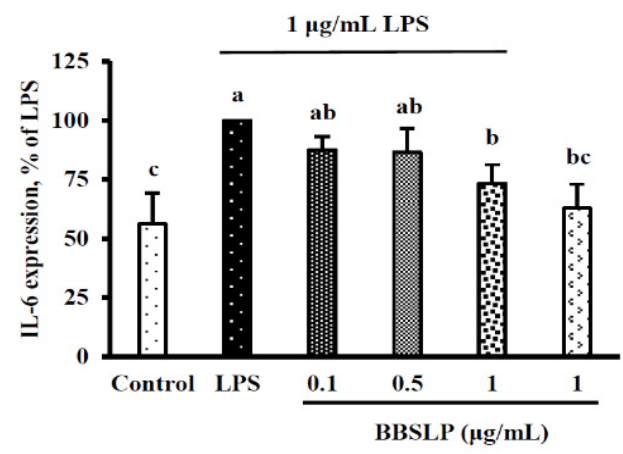

D

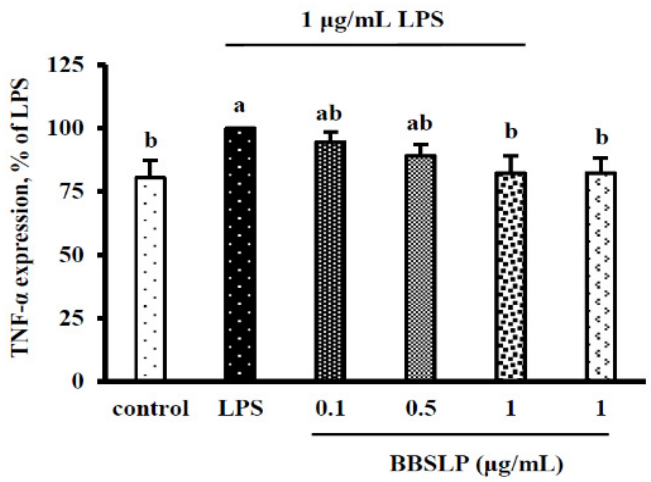

Figure 5. Effects of BBSLP on the inflammatory response in RAW264.7 cells induced by LPS. RAW264.7 cells $\left(1 \times 10^{5}\right.$ cells/30-mm plate) were seeded and cultured overnight, treated with $0.1,0.5$ or $1 \mu \mathrm{g} / \mathrm{mL}$ BBSLP for $24 \mathrm{~h}$ and then induced or not with $1 \mu \mathrm{g} / \mathrm{mL}$ LPS for another $24 \mathrm{~h}$. The group treated with $1 \mu \mathrm{g} / \mathrm{mL}$ LPS alone served as an induced control group. BBSLP was diluted in sterilized $\mathrm{H}_{2} \mathrm{O}$, and cells treated with sterilized $\mathrm{H}_{2} \mathrm{O}$ alone served as the control group. Cells treated with $1 \mu \mathrm{g} / \mathrm{mL}$ BBSLP without LPS treatment for $48 \mathrm{~h}$ were used as another control group. Levels of NOIL-1 $\beta$ (A), IL-6 (B), IL-10 (C), and TNF- $\alpha$ (D) were examined. Values are presented as means $\pm \mathrm{SD}(n=3-5)$. abc Values are significantly different from the other groups as determined by Tukey's test $(p<0.05)$.

\subsection{BBSLP Reduced the Activation of NF-kB Signalling in RAW264.7 Cells after LPS Induction}

Figure $6 \mathrm{~A}, \mathrm{~B}$ show that IкB phosphorylation was significantly reduced by $20-50 \%$ after $0,1,0.5$ or $1 \mu \mathrm{g} / \mathrm{mL}$ BBSLP treatment in RAW264.7 cells induced with LPS $(p<0.05)$. However, BBSLP did not affect the protein contents of cytosolic I- $\mathrm{kB}$ in EA.hy926 cells (Figure $6 \mathrm{~A}, \mathrm{~B}$ ). The nuclear NF- $\mathrm{KB}$ levels were significantly decreased by $24 \%$ and $16 \%$, respectively, after 0.5 or $1 \mu \mathrm{g} / \mathrm{mL}$ BBELP treatment in RAW264.7 cells induced by LPS $(p<0.05$, Figure $6 \mathrm{~A}, \mathrm{~B})$. The DNA-binding activity of nuclear NF- $\mathrm{kB}$ was significantly suppressed by $49 \%$ in cells treated with $100 \mu \mathrm{g} / \mathrm{mL}$ BBSLP (Figure $6 \mathrm{C}$ ). 
A

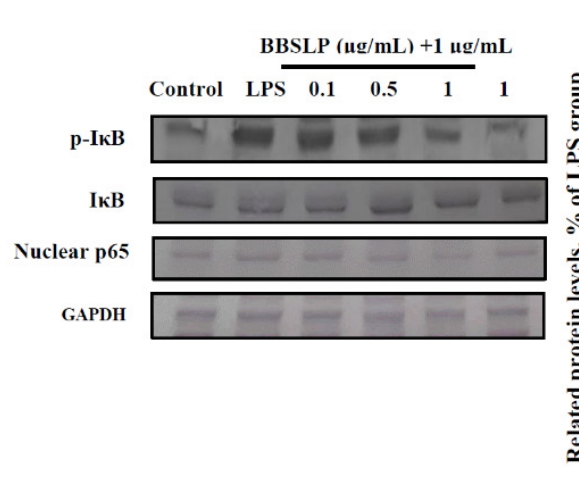

B

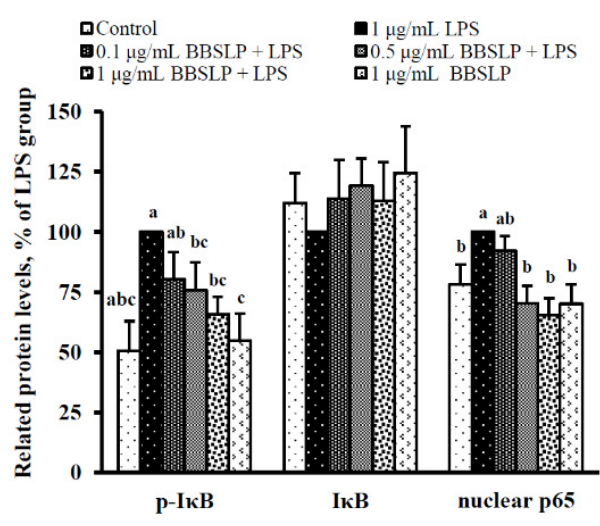

C

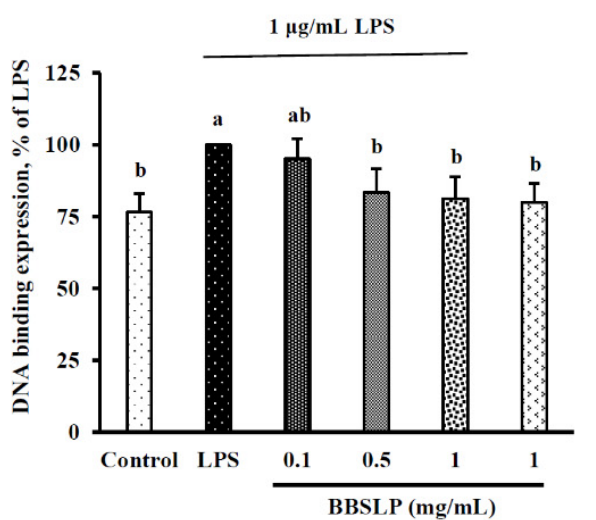

Figure 6. Effects of BBSLP on NF-kB signalling activation in LPS-induced RAW264.7 cells. RAW264.7 cells $\left(1 \times 10^{5}\right.$ cells $/ 30$-mm plate) were seeded and cultured overnight, treated with $0.1,0.5$ or $1 \mu \mathrm{g} / \mathrm{mL}$ BBSLP for $24 \mathrm{~h}$ and then induced or not with $1 \mu \mathrm{g} / \mathrm{mL}$ LPS for another $24 \mathrm{~h}$. The group treated with $1 \mu \mathrm{g} / \mathrm{mL}$ LPS alone served as an induced control group. BBSLP was diluted in sterilized $\mathrm{H}_{2} \mathrm{O}$, and cells treated with sterilized $\mathrm{H}_{2} \mathrm{O}$ alone served as the control group. Cells treated with $1 \mu \mathrm{g} / \mathrm{mL}$ BBSLP without LPS treatment for $48 \mathrm{~h}$ were used as another control group. Phosphorylated

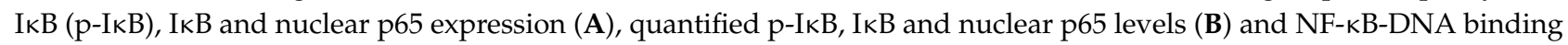
activity $(C)$ were examined. Values are presented as means $\pm \operatorname{SD}(n=3-5)$. ${ }^{\text {abc }}$ Values are significantly different from the other groups as determined by Tukey's test $(p<0.05)$.

\section{Discussion}

The present study showed that BBSLP has the ability of free radical scavage and reducing power enhance in vitro. And, the potential antioxidant and anti-inflammatory effects of BBSLP in LPS-induced RAW264.7 macrophages. Because BBSLP significantly reduced oxidative stress, including an ability to decrease levels of free radicals and lipid peroxidation, and reduced pro-inflammation molecules, including IL-1 $\beta$, IL-6 and TNF- $\alpha$ levels, in LPS-induced RAW264.7 cells.

Our results found that BBSLP contained flavonoids and polyphenols, which were may be involved in its high antioxidative and anti-inflammatory properties. Glevitzky et al. [24] showed that there are a high intercorrelation between the number of phenolic groups within the basic structure of flavonoids and their antioxidant activity and between the antioxidant activity and the number of $-\mathrm{OH}$ phenolic groups also with a high correlation. However, polyphenols or the other components of BBSL and BBSLP whether playing a major or important role in antioxidation or not, are still need furthermore composition analysis and investigation. Inflammatory response mediators, including $\mathrm{PGE}_{2}$ and $\mathrm{NO}$, and inflammatory cytokines, including IL-1 $\beta$, IL-6, IL-10 and TNF- $\alpha$, were all regulated, reducing inflammation in LPS-induced RAW264.7 cells. Furthermore, BBSLP could downregulate NF- $\kappa B$ signalling activation, which led to reduced iNOS, COX-2, IL-1 $\beta$, IL-6, IL-10 and TNF- $\alpha$ transcription.

Oxidative stress usually triggers the inflammatory response in various cells and tissues [25]. Macrophages then use ROS production to scavenge xenobiotics, including bacteria and oxidized low-density lipoprotein (ox-LDL) [26]. Long-term inflammation, chronic inflammation and oxidative stress lead to chronic diseases, such as CKD, CVD, $\mathrm{DM}$ and sepsis with a poor prognosis. In the present study, BBSLP displayed excellent free radical-scavenging ability, reducing power and SOD activity in an in vitro model and significantly reduced ROS production and TBARS levels in LPS-induced RAW264.7 cells. The above excellent antioxidative effects were from the polyphenols and isoflavones contained in BBSLP. Takahashi et al. [27] showed that the seed coats of black soybeans have a higher total polyphenol content than those of yellow soybeans. Black soybeans may more effectively inhibit LDL oxidation than yellow soybeans because of the higher 
total polyphenol contents in their seed coat. Additionally, cyanidin-3-glucoside, petunidin3-glucoside and peonidin-3-glucoside, three major anthocyanins, have been detected in black soybean seed coats [3]. DPPH radical scavenging, $\mathrm{ABTS}^{+}$radical scavenging and ferric reducing antioxidant power (FRAP) analysis results have also shown that the black soybean seed coat is a more efficient reducing agent than dehulled black soybeans and yellow soybean coats [3]. In addition, black soybeans are rich in polyphenols, including isoflavones, anthocyanidins and flavan-3-ols. Moreover, black soybeans can prevent CVD risks by increasing polyphenol concentrations and decreasing oxidative stress in healthy women [28]. Previous studies in different experimental models have shown that polyphenols and isoflavones also have anti-inflammatory characteristics. Takekawa et al. [29] showed that genistein, a soybean polyphenol, can significantly suppress water immersion restraint (WIR) stress-induced gastric mucosal injury. The underlying mechanism involves a significant elevation of SOD activity and significant suppression of both TBARS levels and the production of TNF- $\alpha$ to protect against gastric mucosal injury [29]. Additionally, puerarin, an isoflavonoid extracted from Kudzu roots, reduces malondialdehyde levels, increases SOD activity and alleviates TNF- $\alpha$, IL- $1 \beta$ and IL- 6 protein levels in the hippocampus. Antioxidation and anti-inflammation are induced by the streptozotocin (STZ) group to protect DM rats from cognitive deficits [30].

In addition, resveratrol, a polyphenol constituent of grapes, acts as a COX suppressor, reducing the inflammatory response similarly to a nonsteroidal anti-inflammatory drug (NSAID). A molecular basis for the mutually beneficial relationship between plants and humans has been speculated [31]. Hussain et al. [32] reported the anti-inflammatory and antioxidative properties of polyphenols, the mechanisms by which polyphenols inhibit molecular signalling pathways that have been activated by oxidative stress, and the roles of polyphenols in inflammation-mediated chronic disorders. The above data and previous reports indicate that BBSLP, an extract rich in polyphenols and isoflavones, can significantly reduce oxidative stress, inhibit IL-1 $\beta$, IL- 6 and TNF- $\alpha$ and increase IL-10 as an anti-inflammatory material in RAW264.7 macrophages. BBSLP may be helpful for the development of future antioxidant therapeutics and new anti-inflammatory drugs [33].

In the present study, BBSLP significantly inhibited NF- $\kappa B$ signalling activity by reducing I- $\mathrm{KB}$ phosphorylation and NF- $\mathrm{kB}-\mathrm{DNA}$ binding activity. NF- $\mathrm{kB}$ signalling plays an important role in iNOS, COX-2, IL-1 $\beta$, IL-6 and TNF- $\alpha$ transcription [15,19-22]. Previous studies have shown that one of the major mechanisms of reducing inflammation is to reduce NF- $\mathrm{KB}$ signalling activity and the expression of proinflammatory molecules [23]. Bao et al. [34] showed that chlorogenic acid, a major polyphenol compound from coffee, can prevent diabetic nephropathy by inhibiting oxidative stress and inflammation through the reduction of NF- $\mathrm{kB}$ signalling activity. Singh et al. [35] also reported that polyphenols have antioxidative and anti-neuroinflammatory properties by regulating NF- $\mathrm{KB}$ activation in neurodegenerative diseases.

Currently, the food supply chain is facing substantial pressures, including the availability of fewer natural resources and increased food waste [23]. One important way to increase the food supply and decrease the environmental consequences of current food production is to reduce food waste levels and their economic, environmental and social implications [36]. Previous studies have shown that various by-products from the manufacturing of animals and plants for food contain various fatty acids [37], phytochemicals [38,39], and amino acids [40], all of which are beneficial to the food supply chain and/or can act as health promoters for food sustainability. In the present study, BBSLP showed potential antioxidant and anti-inflammatory effects. In the present study, BBSLP showed preliminary potential on antioxidant and anti-inflammatory effects in vitro. However, the molecular mechanisms of the physiological effects require further study in animal models or human clinical trials. On the other hand, how does BBSLP apply in function foods? Where BBSLP to be developed into a functional food material, a functional assessment of this product is needed. The above questions are an important issue for BBSLP application. 


\section{Materials and Methods}

\subsection{Materials}

BBSL was a gift from Ta-Tung Soya Sauce Co., Ltd., located in Siluo Town (Yunlin, Taiwan). BBSL is collected from the soybean sauce manufacturing process. After fresh black beans are washed and steamed by $120^{\circ} \mathrm{C}$ streams in a closed steam tank for $1 \mathrm{~h}$. BBSL were directly collected as experimental materials. LPS was purchased from Sigma-Aldrich Co. (St. Louis, MO, USA).

\subsection{Preparation of BBSLP}

According to our previous methods [41], BBSLP was prepared by our laboratory. Fresh BBSL was concentrated in a rotary evaporator (N-1110, Tokyo Rikakikai Co., Ltd., Tokyo, Japan) and then dried in a freeze dryer (Freezone 4.5, Labconco, Kansas City, MO, USA) at $-43{ }^{\circ} \mathrm{C}$. The BBSLP was stored at $-20^{\circ} \mathrm{C}$ until use. The percent yield of BBSLP was $1.16 \%(w / v)$.

\subsection{Determination of the $p H$ Value and Total Flavonoids, Phenols and Protein in BBSL and BBSLP}

The $\mathrm{pH}$ values of fresh BBSL were measured using a $\mathrm{pH}$ metre (MP220 $\mathrm{pH}$ meter, Mettler Toledo, Greifensee, Switzerland). The total phenol contents were analysed using a colorimetric method according to Padmavati et al. [42]. One hundred microlitres of $1 \mathrm{~N}$ Folin-Ciocalteu reagent (Sigma-Aldrich Co.) was added to $100 \mu \mathrm{L}$ of diluted BBSL or BBSLP (dissolved in reverse-osmosis (RO) $\mathrm{H}_{2} \mathrm{O}$ ). Then, $500 \mu \mathrm{L}$ of $7.5 \% \mathrm{Na}_{2} \mathrm{CO}_{3}$ solution was added to react for $30 \mathrm{~min}$, and the absorbance of each sample was measured at an optical density (OD) of $760 \mathrm{~nm}$ in a Biokinetics microplate reader (Bio-Tek Instruments, Winooski, VT, USA). Calibration curves were constructed using $0,0.125,0.25$ and $0.5 \mathrm{mg} / \mathrm{mL}$ gallic acid (GA). The total phenolic content is represented as $\mathrm{mg} \mathrm{GAE} / \mathrm{mL}$ BBSL or mg GAE/g BBSLP.

The flavonoid content was analysed using the colorimetric method according to Jia et al. [43]. One hundred microlitres of $5 \% \mathrm{NaNO}_{3}$ solution was added to $100 \mu \mathrm{L}$ of the BBSL or BBSLP solution to react for $5 \mathrm{~min}$. Then, $50 \mu \mathrm{L}$ of $10 \% \mathrm{AlCl}_{3}$ solution was added. Finally, $600 \mu \mathrm{L}$ of $4 \% \mathrm{NaOH}$ solution was added to the mixture for $30 \mathrm{~min}$. The absorbance of the mixture was measured at OD $510 \mathrm{~nm}$ on the Biokinetics microplate reader. Calibration curves were constructed with $0,0.02,0.06,0.08$ and $0.1 \mathrm{mg} / \mathrm{mL}$ rutin (RU) as the standard. The total flavonoid content is represented as mg RUE/mL BBSL or mg RUE/g BBSLP.

Crude protein contents were analysed according to Lowry et al. [44]. Fifty microlitres of each standard of BBSL or BBSLP was added to $50 \mu \mathrm{L}$ of trichloroacetic acid and standing for reacted for $30 \mathrm{~min}$ at room temperature. The mixture was centrifuged at $15,000 \times \mathrm{g}$ for $20 \mathrm{~min}$ at $4{ }^{\circ} \mathrm{C}$. Then, the supernatant was discarded. The precipitate was dissolved in $1 \mathrm{~mL}$ of $\mathrm{NaOH}$ and standing for reacted for $30 \mathrm{~min}$ at room temperature. Then, $1.0 \mathrm{~mL}$ of modified Lowry Reagent (Sigma-Aldrich Co.) was added, then mixing and incubation at room temperature for $10 \mathrm{~min}$. Five hundred $\mu \mathrm{L}$ Prepared 1X Folin-Ciocalteu's phenol reagent (Sigma-Aldrich Co.) was added, and the mixture was standing in a water bath at $37^{\circ} \mathrm{C}$ for $30 \mathrm{~min}$. After $30 \mathrm{~min}$, the absorbance was measured at $660 \mathrm{~nm}$ on the Biokinetics microplate reader.

\subsection{In Vitro Antioxidant Ability of BBSLP}

In this study, DPPH (Sigma-Aldrich Co.) radical scavenging activity by BBSLP was analysed according to the method of Shimada et al. [45]. For the measure of the DPPH radical-scavenging activity, $1.5 \mathrm{~mL}$ of the sample solution with varying BBSLP concentrations $(0.5,1,2$ and $4 \mathrm{mg} / \mathrm{mL})$ were added $1.5 \mathrm{~mL}$ of $0.15 \mathrm{mM}$ DPPH in $50 \%$ ethanol. The mixture was mixed and incubated at room temperature in the dark for $30 \mathrm{~min}$. The optical density at $517 \mathrm{~nm}$ was measured using the Biokinetics microplate reader. In this test, $1 \mathrm{mg} / \mathrm{mL}$ vitamin $C$ was used as a control. The scavenging activity was calculated as $\left(1-A_{\text {BBSLP }}\right.$ or $\left.A_{\text {vitamin } C} / A_{\text {blank }}\right) \times 100$. 
According to the method of Shimada et al. [45] to analyse the reducing power activity of BBSLP in vitro. Here, $0.5 \mathrm{~mL}$ of the $0.5,1,2$ and $4 \mathrm{mg} / \mathrm{mL}$ BBSLP, respectively were mixed with $2.5 \mathrm{~mL}$ of $0.2 \mathrm{M}$ phosphate buffer ( $\mathrm{pH} 6.6)$ and $2.5 \mathrm{~mL}$ of $1 \%$ potassium ferricyanide, then the mixture was incubated at $50{ }^{\circ} \mathrm{C}$ for $20 \mathrm{~min}$. A $2.5 \mathrm{~mL}$ aliquot of $10 \%$ trichloroacetic acid was added to the mixture, and the mixture was then centrifuged at $3000 \times g$ for $10 \mathrm{~min}$. The supernatant $(2.5 \mathrm{~mL})$ was mixed with $2.5 \mathrm{~mL}$ of distilled water and $2.5 \mathrm{~mL}$ of $0.1 \%$ ferric chloride, and the absorbance at $700 \mathrm{~nm}$ was read using the microplate reader. The reducing power was calculated as $\left(\mathrm{A}_{\mathrm{BBSLP}}\right.$ or $\left.\mathrm{A}_{\text {vitamin } C}-\mathrm{A}_{\text {blank }}\right) / \mathrm{A}_{\text {vitamin } C} \times 100$. A vitamin $\mathrm{C}(1 \mathrm{mg} / \mathrm{mL})$ was used as a control.

The $\mathrm{ABTS}^{+}$radical scavenging ability of $0.5,1,2$ or $4 \mathrm{mg} / \mathrm{mL}$ BBSLP was analysed according to the method described by Re et al. [46]. Use a $10 \mu \mathrm{L}$ of the sample solution with varying BBSLP concentrations $(0.5,1,2$ and $4 \mathrm{mg} / \mathrm{mL})$ were added $990 \mu \mathrm{L}$ of $2 \mathrm{mM}$ 2,2'-azino-bis(3-ethylbenzothiazoline-6-sulfonate) radical cation (ABTS ${ }^{\bullet+}$ ) solution. The mixture was mixed and incubated at room temperature in the dark for $10 \mathrm{~min}$. The optical density at $737 \mathrm{~nm}$ was measured using the microplate reader. The $\mathrm{ABTS}^{+}$radicalscavenging ability was calculated as $\left(\mathrm{A}_{\text {blank }}\right.$ or $\left.\mathrm{A}_{\mathrm{BBSLP}}-\mathrm{A}_{\text {Trolox }}\right) / \mathrm{A}_{\text {blank }} \times 100$. In this test, $1 \mathrm{mg} / \mathrm{mL}$ Trolox was used as a control.

\subsection{Cell Culture and Treatment}

RAW264.7 macrophages and mouse monocyte macrophages were purchased from the Bioresource Collection and Research Center (Hsinchu, Taiwan). Dulbecco's modified Eagle's medium containing $42 \mathrm{mM}$ L-glutamine, $100 \mathrm{units} / \mathrm{mL}$ penicillin, $100 \mu \mathrm{g} / \mathrm{mL}$ streptomycin and 10\% $(v / v)$ heat-inactivated fetal bovine serum (FBS; Gibco, Thermo Fisher Scientific, Inc., Waltham, MA, USA) was used as the culture medium. All cultured cells were incubated in an atmosphere of $5 \% \mathrm{CO}_{2} / 95 \%$ air at $37^{\circ} \mathrm{C}$.

In this study, $1 \times 10^{5}$ RAW264.7 macrophages per $30 \mathrm{~mm}$ plate or $1 \times 10^{6}$ per $60 \mathrm{~mm}$ plate were cultured for various biochemical tests. RAW264.7 macrophages were incubated with $0.5,1$ or $5 \mu \mathrm{g} / \mathrm{mL}$ BBSLP for $24 \mathrm{~h}$ and then induced with $1 \mu \mathrm{g} / \mathrm{mL}$ LPS (Sigma-Aldrich Co.) for another $24 \mathrm{~h}$. LPS was used to induce inflammation [47]. The induced control group was treated with $1 \mu \mathrm{g} / \mathrm{mL}$ LPS alone. BBSLP was soluble in sterilized $\mathrm{H}_{2} \mathrm{O}$, and cells treated with sterilized $\mathrm{H}_{2} \mathrm{O}$ alone served as the control group. BBSLP $(1 \mu \mathrm{g} / \mathrm{mL})$ without LPS treatment for $48 \mathrm{~h}$ made up another control group.

\subsection{Cell Viability Analysis}

To determine the optimum test concentration of BBSLP for use in this study, the cell viability of RAW264.7 macrophages was analysed according to the method of Denizot and Lang [48]. After RAW264.7 macrophages were incubated in DMEM containing $0.5 \mathrm{mg} / \mathrm{mL}$ thiazolyl blue formazan (MTT; Sigma-Aldrich Co.) for an additional $3 \mathrm{~h}$, the medium was removed and extracted with isopropanol for $15 \mathrm{~min}$. The isopropanol fraction was measured with the Biokinetics microplate reader at OD $570 \mathrm{~nm}$. To evaluate morphological changes, a phase-contrast inverted fluorescence microscope (Olympus IX51, Olympus, Tokyo, Japan) was used.

\subsection{Measurement of Lipid Peroxidation and ROS Levels}

The effect of BBSLP on lipid peroxidation in RAW264.7 macrophages induced by LPS was determined according to the method of Fraga et al. [49]. The lipid peroxidation indicator thiobarbituric acid reactive substances (TBARS) was extracted and measured with a fluorescence microplate reader (excitation wavelength $515 \mathrm{~nm}$ and emission wavelength $555 \mathrm{~nm}$, Bio-Tek Instruments, Winooski, VT, USA). The protein levels were determined according to the method described by Lowry et al. [44]. The TBARS level is shown in nmol TBARs / mg protein. The levels of ROS in RAW364.7 cells were determined using a Cellular ROS Assay Kit (ab113851, Abcam Inc., Cambridge, MA, USA). 


\subsection{Determination of Nitrite (NO) and Prostaglandin $E_{2}\left(P G E_{2}\right)$}

To determine the inflammation level in RAW 264.7 cells, the Griess assay was used [50]. Griess reagent (1\% sulfanilamide/0.1\% N-(1-naphtyl)ethylene diamine dihydrochloride in $2.5 \% \mathrm{H}_{3} \mathrm{PO}_{4}$ ) was mixed with an equal part of the cell culture medium of control or various experimental groups RAW 264.7 cells. In this test, the $\mathrm{NO}_{2}$ content was used as an indicator of NO content in RAW364.7 macrophages. The OD $550 \mathrm{~nm}$ was determined and calibrated using a standard curve of $\mathrm{NaNO}_{2}$ prepared in culture medium.

The PGE $_{2}$ levels in RAW264.7 macrophages were determined using an enzyme immunoassay (EIA) kit (ADI-900-001, Cayman Chemical, Ann Arbor, MI, USA). The cell culture supernatants were collected after experimental treatment and centrifuged at $1000 \times g$ for $15 \mathrm{~min}$ to remove the particulate matter. The medium and PGE2 EIA conjugate was added to a 96-well plate pre-coated with goat anti-mouse IgG and left to react for $1 \mathrm{~h}$, followed by a final wash to remove any unbound antibody-enzyme reagent. A substrate solution was added and the intensity of the color produced was measured at $412 \mathrm{~nm}$. The concentration of $\mathrm{PGE}_{2}$ in each sample was calculated according to $\mathrm{PGE}_{2}$ standards.

\subsection{Measurement of IL-1 $\beta, I L-6$ and TNF- $\alpha$}

The levels of IL-1 $\beta$, IL- 6 and TNF- $\alpha$ in RAW264.7 macrophages were analysed using rat IL-1 $\beta /$ IL-1F2 DuoSet ELISA (R\&D, DY501-05), rat IL-6 DuoSet ELISA (R\&D, DY506-05), and rat TNF- $\alpha$ DuoSet ELISA (R\&D, DY510-05) kits (R\&D Systems, Inc., Minneapolis, MN, USA), respectively, according to the manufacturer's instructions. In brief, capture antibodies, cultured medium supernatants, detection antibodies, streptavidin-conjugated horseradish-peroxidase were processed on the plate in order, and the color subtract tetramethylbenzidine was used. The absorbance was measured and the concentration was calculated according to the standard.

\subsection{Immunoblot Analyses of $i N O S, C O X-2$ and NF- $\kappa B$ Signalling Molecule Expression}

The iNOS, COX-2 and NF- $\mathrm{kB}$ signalling molecule expression was analysed using the method described by Hsieh et al. [51]. At the end of the treatment, the cells were collected in $200 \mu \mathrm{L}$ of lysis buffer (10 mM Tris-HCl, $5 \mathrm{mM}$ EDTA, $0.2 \mathrm{mM}$ phenylmethylsulfonyl fluoride and $20 \mu \mathrm{g} / \mathrm{mL}$ aprotinin, $\mathrm{pH}$ 7.4), and the protein content was determined according to the method of Lowry et al. [44].

Equal amounts (approximately 10-20 $\mu$ g per sample) of cellular protein were separated by $10 \%$ sodium dodecyl sulfate (SDS) polyacrylamide gel electrophoresis (PAGE) [52], after which the samples were transferred to polyvinylidene difluoride (PVDF) membranes [53]. The PVDF membranes were then incubated with anti-iNOS, anti-COX-2, anti-p-IkB, anti$\mathrm{I} \mathrm{KB}$, anti-NF- $\mathrm{KB}$ (p65) or anti-GAPDH antibodies at $4{ }^{\circ} \mathrm{C}$ overnight, followed by incubation with a peroxidase-conjugated secondary antibody. For density analysis, blots were treated with enhanced chemiluminescence substrate solutions and exposed using a ChemiDoc XRSt System (Bio-Rad Laboratories, Hercules, CA, USA). An NF-kB (p65) transcription factor activity assay kit (Cayman Chemical Co.) was used to analyse the NF-kB DNA binding activity of the nuclear fraction.

\subsection{Statistical Analysis}

The SPSS Statistical Analysis Software for Windows, version 20.0 (SPSS Inc., Chicago, IL, USA) was used to analyse the experimental data in the present study. One-way analysis of variance (ANOVA) and Duncan's or Tukey's multiple-range test were used to evaluate the significance of differences between each mean value. A $p$-value less than 0.05 was used to indicate a statistically significant result.

\section{Conclusions}

In conclusion, the presented data in this study demonstrate that BBSLP could reduce oxidative stress and pro-inflammation factors in LPS-induced RAW264.7 cells through the inhibition of the NF- $\mathrm{kB}$ signaling pathway, indicating that it may have potent antioxi- 
dant and anti-inflammatory capabilities, suggesting that BBSLP could be developed as a supplement material for functional foods.

Author Contributions: Conceptualization, S.-L.H., S.-F.T. and C.-C.W.; Methodology, S.-L.H. and Y.-M.C.; Validation, Y.-W.S., C.-C.L. and C.-C.W.; Formal Analysis, Y.-M.C.; Investigation, Y.-W.S. and S.-L.H.; Resources, Y.-M.C. and S.-F.T.; Data Curation, Y.-W.S. and C.-C.W.; Writing-Original Draft Preparation, C.-C.W.; Writing-Review \& Editing, S.-L.H. and C.-C.W.; Supervision, C.-C.W.; Project Administration, C.-C.W. All Authors read and approved the article and agree to be accountable for all aspects of the research and ensure that the accuracy or integrity of any part of the work is appropriately investigated and resolved. All authors have read and agreed to the published version of the manuscript.

Funding: This work was supported by Ta-Tung Soya Sauce Co. Ltd. through a grant (grant no. PU108-11150-A002).

Institutional Review Board Statement: Not applicable.

Informed Consent Statement: Not applicable.

Data Availability Statement: The datasets used and/or analyzed during the present study are available from the corresponding author on reasonable request.

Conflicts of Interest: The authors declare no conflict of interest.

\section{References}

1. O'Toole, D.K. The role of microorganisms in soy sauce production. Adv. Appl. Microbiol. 2019, 108, 45-113. [CrossRef] [PubMed]

2. Teigiserova, D.; Hamelin, L.; Thomsen, M. Towards transparent valorization of food surplus, waste and loss: Clarifying definitions, food waste hierarchy, and role in the circular economy. Sci. Total. Environ. 2019, 706, 136033. [CrossRef] [PubMed]

3. Domae, C.; Nanba, F.; Maruo, T.; Suzuki, T.; Ashida, H.; Yamashita, Y. Black soybean seed coat polyphenols promote nitric oxide production in the aorta through glucagon-like peptide-1 secretion from the intestinal cells. Food Funct. 2019, 10, 7875-7882. [CrossRef] [PubMed]

4. Diez-Simon, C.; Eichelsheim, C.; Mumm, R.; Hall, R.D. Chemical and sensory characteristics of soy sauce: A Review. J. Agric. Food Chem. 2020, 68, 11612-11630. [CrossRef]

5. Choi, Y.-M.; Yoon, H.; Lee, S.; Ko, H.-C.; Shin, M.-J.; Lee, M.C.; Hur, O.S.; Ro, N.Y.; Desta, K.T. Isoflavones, anthocyanins, phenolic content, and antioxidant activities of black soybeans (Glycine max (L.) Merrill) as affected by seed weight. Sci. Rep. 2020, 10, 19960. [CrossRef]

6. Yamashita, Y.; Nakamura, A.; Nanba, F.; Saito, S.; Toda, T.; Nakagawa, J.; Ashida, H. Black soybean improves vascular function and blood pressure: A randomized, placebo controlled, crossover trial in humans. Nutrients 2020, 12, 2755. [CrossRef]

7. Chen, Z.; Wang, C.; Pan, Y.; Gao, X.; Chen, H. Hypoglycemic and hypolipidemic effects of anthocyanins extract from black soybean seed coat in high fat diet and streptozotocin-induced diabetic mice. Food Funct. 2017, 9, 426-439. [CrossRef] [PubMed]

8. Takagi, A.; Kano, M.; Kaga, C. Possibility of breast cancer prevention: Use ofsoy isoflavones and fermented soy beverage produced using probiotics. Int. J. Mol. Sci. 2015, 16, 10907-10920. [CrossRef]

9. Ganesan, K.; Xu, B. A Critical review on polyphenols and health benefits of black soybeans. Nutrients 2017, 9, 455. [CrossRef]

10. Tit, D.M.; Bungau, S.; Iovan, C.; Cseppento, D.C.N.; Endres, L.; Sava, C.; Sabau, A.M.; Furau, G.; Furau, C. Effects of the hormone replacement therapy and of soy isoflavones on bone resorption in postmenopause. J. Clin. Med. 2018, 7, 297. [CrossRef]

11. Rao, D.E.; Chaitanya, K.V. Changes in the antioxidant intensities of seven different soybean (Glycine max (L.) Merr.) cultivars during drought. J. Food Biochem. 2020, 44, e13118.

12. Kim, J.N.; Han, S.N.; Ha, T.J.; Kim, H.-K. Black soybean anthocyanins attenuate inflammatory responses by suppressing reactive oxygen species production and mitogen activated protein kinases signaling in lipopolysaccharide-stimulated macrophages. Nutr. Res. Pract. 2017, 11, 357-364. [CrossRef]

13. Kim, M.Y.; Jang, G.Y.; Lee, Y.; Li, M.; Ji, Y.M.; Yoon, N.; Lee, S.H.; Kim, K.M.; Lee, J.; Jeong, H.S. Free and bound form bioactive compound profiles in germinated black soybean (Glycine max L.). Food Sci. Biotechnol. 2016, 25, 1551-1559. [CrossRef]

14. Rajendran, P.; Chen, Y.; Chen, Y.; Chung, L.; Tamilselvi, S.; Shen, C.; Day, C.H.; Chen, R.; Viswanadha, V.P.; Kuo, W.; et al. The multifaceted link between inflammation and human diseases. J. Cell. Physiol. 2018, 233, 6458-6471. [CrossRef]

15. Infantino, V.; Pierri, C.L.; Iacobazzi, V. Metabolic routes in inflammation: The citrate pathway and its potential as therapeutic target. Curr. Med. Chem. 2020, 26, 7104-7116. [CrossRef] [PubMed]

16. Kondo, N.; Kuroda, T.; Kobayashi, D. Cytokine networks in the pathogenesis of rheumatoid arthritis. Int. J. Mol. Sci. 2021, 22, 10922. [CrossRef]

17. Li, L.; Yu, R.; Cai, T.; Chen, Z.; Lan, M.; Zou, T.; Wang, B.; Wang, Q.; Zhao, Y.; Cai, Y. Effects of immune cells and cytokines on inflammation and immunosuppression in the tumor microenvironment. Int. Immunopharmacol. 2020, 88, 106939. [CrossRef] [PubMed] 
18. Donate-Correa, J.; Ferri, C.M.; Sánchez-Quintana, F.; Pérez-Castro, A.; González-Luis, A.; Martín-Núñez, E.; Mora-Fernández, C.; Navarro-González, J.F. Inflammatory cytokines in diabetic kidney disease: Pathophysiologic and therapeutic implications. Front. Med. 2021, 7, 1137. [CrossRef]

19. Mitchell, J.P.; Carmody, R.J. NF-кB and the transcriptional control of inflammation. Int. Rev. Cell Mol. Biol. 2018, 335, 41-84.

20. Zhao, H.; Wu, L.; Yan, G.; Chen, Y.; Zhou, M.; Wu, Y.; Li, Y. Inflammation and tumor progression: Signaling pathways and targeted intervention. Signal. Transduct. Target. Ther. 2021, 6, 1-46. [CrossRef] [PubMed]

21. Toker, H.; Görgün, E.P.; Korkmaz, E.M. Analysis of IL-6, IL-10 and NF-kappaB gene polymorphisms in aggressive and chronic periodontitis. Cent. Eur J. Public Health. 2017, 25, 157-162. [CrossRef]

22. Kunnumakkara, A.B.; Shabnam, B.; Girisa, S.; Harsha, C.; Banik, K.; Devi, T.B.; Choudhury, R.; Sahu, H.; Parama, D.; Sailo, B.L.; et al. Inflammation, NF-kappaB, and chronic diseases: How are they linked? Crit. Rev. Immunol. 2020, 40, 1-39. [CrossRef] [PubMed]

23. Dutta, S.; He, M.; Xiong, X.; Tsang, D.C. Sustainable management and recycling of food waste anaerobic digestate: A review. Bioresour. Technol. 2021, 341, 125915. [CrossRef] [PubMed]

24. Glevitzky, I.; Dumitrel, G.A.; Glevitzky, M.; Pasca, B.; Otř́isal, P.; Bungau, S.; Cioca, G.; Pantis, C.; Popa, M. Statistical analysis of the relationship between antioxidant activity and the structure of flavonoid compounds. Rev. Chim. 2019, 70, 3103-3107. [CrossRef]

25. de Bhailís, B.; Chrysochou, C.; Kalra, P. Inflammation and oxidative damage in ischaemic renal disease. Antioxidants 2021, 10, 845. [CrossRef]

26. Marchio, P.; Guerra-Ojeda, S.; Vila, J.M.; Aldasoro, M.; Victor, V.M.; Mauricio, M.D. Targeting early atherosclerosis: A focus on oxidative stress and inflammation. Oxid. Med. Cell. Longev. 2019, 2019, 8563845. [CrossRef] [PubMed]

27. Takahashi, R.; Ohmori, R.; Kiyose, C.; Momiyama, Y.; Ohsuzu, A.F.; Kondo, K. Antioxidant activities of black and yellow soybeans against low density lipoprotein Oxidation. J. Agric. Food Chem. 2005, 53, 4578-4582. [CrossRef]

28. Yamashita, Y.; Wang, L.; Nakamura, A.; Nanba, F.; Saito, S.; Toda, T.; Nakagawa, J.; Ashida, H. Black soybean improves the vascular function through an increase in nitric oxide and a decrease in oxidative stress in healthy women. Arch. Biochem. Biophys. 2020, 688, 108408. [CrossRef]

29. Takekawa, S.; Matsui, T.; Arakawa, Y. The protective effect of the soybean polyphenol genistein against stress-induced gastric mucosal lesions in rats, and its hormonal mechanisms. J. Nutr. Sci. Vitaminol. 2006, 52, 274-280. [CrossRef]

30. Liu, X.; Mo, Y.; Gong, J.; Li, Z.; Peng, H.; Chen, J.; Wang, Q.; Ke, Z.; Xie, J. Puerarin ameliorates cognitive deficits in streptozotocininduced diabetic rats. Metab. Brain Dis. 2015, 31, 417-423. [CrossRef]

31. Inoue, H.; Nakata, R. Resveratrol targets in inflammation. Endocr. Metab. Immune Disord. Drug Targets. 2015, 15, 186-195. [CrossRef]

32. Hussain, T.; Tan, B.; Yin, Y.; Blachier, F.; Tossou, M.C.; Rahu, N. Oxidative stress and inflammation: What polyphenols can do for us? Oxid. Med. Cell Longev. 2016, 2016, 7432797. [CrossRef]

33. Thawkar, B.S.; Kaur, G.J. Inhibitors of NF-kappaB and P2X7/NLRP3/Caspase 1 pathway in microglia: Novel therapeutic opportunities in neuroinflammation induced early-stage Alzheimer's disease. J. Neuroimmunol. 2019, 326, 62-74. [CrossRef] [PubMed]

34. Bao, L.; Li, J.; Zha, D.; Zhang, L.; Gao, P.; Yao, T.; Wu, X. Chlorogenic acid prevents diabetic nephropathy by inhibiting oxidative stress and inflammation through modulation of the Nrf2/HO-1 and NF-qB pathways. Int. Immunopharmacol. 2018, 54, 245-253. [CrossRef] [PubMed]

35. Singh, S.S.; Rai, S.N.; Birla, H.; Zahra, W.; Rathore, A.S.; Singh, S.P. NF-kappaB-mediated neuroinflammation in Parkinson's disease and potential therapeutic effect of polyphenols. Neurotox. Res. 2020, 37, 491-507. [CrossRef] [PubMed]

36. Godfray, H.C.; Crute, I.R.; Haddad, L.; Lawrence, D.; Muir, J.F.; Nisbett, N.; Pretty, J.; Robinson, S.; Toulmin, C.; Whiteley, R. The future of global food system. Philos. Trans. R Soc. Lond B Biol. Sci. 2010, 365, 2769-2777. [CrossRef]

37. Benítez, J.J.; Castillo, P.M.; Del Río, J.C.; León-Camacho, M.; Domínguez, E.; Heredia, A.; Guzmán-Puyol, S.; Athanassiou, A.; Heredia-Guerrero, J.A. Valorization of tomato processing by-products: Fatty acid extraction and production of bio-based materials. Materials 2018, 11, 2211. [CrossRef]

38. Li, Q.; Sun, J.; Mohammadtursun, N.; Wu, J.; Dong, J.; Li, L. Curcumin inhibits cigarette smoke-induced inflammation via modulating the PPAR $\gamma$-NF-kB signaling pathway. Food Funct. 2019, 10, 7983-7994. [CrossRef]

39. Lee, K.J.; Baek, D.-Y.; Lee, G.-A.; Cho, G.-T.; So, Y.-S.; Lee, J.-R.; Ma, K.-H.; Chung, J.-W.; Hyun, D.Y. Phytochemicals and antioxidant activity of Korean black soybean (Glycine max L.) Landraces. Antioxidants 2020, 9, 213. [CrossRef]

40. Kerr, B.J.; Urriola, P.E.; Jha, R.; E Thomson, J.; Curry, S.M.; Shurson, G.C. Amino acid composition and digestible amino acid content in animal protein by-product meals fed to growing pigs1. J. Anim. Sci. 2019, 97, 4540-4547. [CrossRef]

41. Hsieh, S.-L.; Tsai, P.-J.; Liu, Y.-C.; Wu, C.-C. Potential effects of antioxidant and serum cholesterol-lowering effects of Gynura bicolor water extracts in Syrian Hamster. Evid. Based Complement. Altern. Med. 2020, 2020, 2907610. [CrossRef]

42. Azeem, S.M.A.; Al Mohesen, I.A.; Ibrahim, A.M. Analysis of total phenolic compounds in tea and fruits using diazotized aminobenzenes colorimetric spots. Food Chem. 2020, 332, 127392. [CrossRef]

43. Paiva, L.; Lima, E.; Motta, M.; Marcone, M.; Baptista, J. Variability of antioxidant properties, catechins, caffeine, L-theanine and other amino acids in different plant parts of Azorean Camellia sinensis. Curr. Res. Food Sci. 2020, 3, 227-234. [CrossRef] [PubMed] 
44. Hsieh, S.L.; Wang, J.C.; Huang, Y.S.; Wu, C.C. Ethanol extract of Gynura bicolor reduces atherosclerosis risk through enhancing antioxidant capacity and reducing adhesion molecule levels. Pharm. Biol. 2021, 59, 504-512. [CrossRef] [PubMed]

45. Shimada, K.; Fujikawa, K.; Yahara, K.; Nakamura, T. Antioxidative properties of xanthan on the autoxidation of soybean oil in cyclodextrin emulsion. J. Agric. Food Chem. 1992, 40, 945-948. [CrossRef]

46. Re, R.; Pellegrini, N.; Proteggente, A.; Pannala, A.; Yang, M.; Rice-Evans, C. Antioxidant activity applying an improved ABTS radical cation decolorization assay. Free Radic. Biol. Med. 1999, 26, 1231-1237. [CrossRef]

47. Han, Y.; Yuan, C.; Zhou, X.; Han, Y.; He, Y.; Ouyang, J.; Zhou, W.; Wang, Z.; Wang, H.; Li, G. Anti-inflammatory activity of three triterpene from Hippophae rhamnoides L. in lipopolysaccharide-stimulated RAW264.7 Cells. Int. J. Mol. Sci. 2021, $22,12009$. [CrossRef]

48. Denizot, F.; Lang, R. Rapid colorimetric assay for cell growth and survival. Modifications to the tetrazolium dye procedure giving improved sensitivity and reliability. J. Immunol. Methods 1986, 89, 271-277. [CrossRef]

49. Fraga, C.G.; Leibovitz, B.E.; Tappel, A.L. Lipid peroxidation measured as thiobarbituric acid-reactive substances in tissue slices: Characterization and comparison with homogenates and microsomes. Free. Radic. Biol. Med. 1988, 4, 155-161. [CrossRef]

50. Green, L.C.; Wagner, D.A.; Glogowski, J.; Skipper, P.L.; Wishnok, J.S.; Tannenbaum, S.R. Analysis of nitrate, nitrite, and [15N]-nitrate in biological fluids. Anal. Biochem. 1992, 126, 131-138. [CrossRef]

51. Hsieh, S.-L.; Wang, J.-J.; Su, K.-H.; Kuo, Y.-L.; Hsieh, S.; Wu, C.-C. Suppressive Effects of the Gynura bicolor Ether Extract on endothelial permeability and leukocyte transmigration in human endothelial cells induced by TNF- $\alpha$. Evid.-Based Complement. Altern. Med. 2020, 2020, 1-13. [CrossRef] [PubMed]

52. Gallagher, S.R. One-dimensional SDS gel electrophoresis of proteins. Curr. Protoc. Toxicol. 2001. [CrossRef]

53. Towbin, H.; Staehelin, T.; Gordon, J. Electrophoretic transfer of proteins from polyacrylamide gels to nitrocellulose sheets: Procedure and some applications. Proc. Natl. Acad. Sci. USA 1979, 76, 4350-4354. [CrossRef] [PubMed] 